\title{
REAL PROPERTY LAW: GALIFORNIA SUPREME COURT UPHOLDS “ON COMPLETION" LEASES UNDER \\ RULE AGAINST PERPETUITIES
}

$\mathrm{O}_{\mathrm{NE}}$ of the most criticized elements of property law is the Rule Against Perpetuities. ${ }^{1}$ Few would argue that the Rule should be eliminated without some substitute, but many feel that its strict application has unnecessarily voided transactions defensible from a policy standpoint. ${ }^{2}$ In recent years courts and legislatures have initiated a definite movement away from such a mechanistic approach. $^{3}$ In Wong $v$. DiGrazia, ${ }^{4}$ the California Supreme Court, sustaining the enforceability of an "on completion" lease, attacked rigid applications of the Rule as being out of step with modern commercial practices.

In the Wong case, plaintiff and defendant sigued a lease which was to commence upon completion of the leased building. ${ }^{5}$ Litigation ensued over a dispute as to which party was to pay for the

\footnotetext{
1 The statutory statement of the Rule Against Perpetuities in California is as follows: "No interest in real or personal property shall be good unless it must vest, if at all, not later than 21 years after some life in being at the creation of the interest and any period of gestation involved in the situation to which the limitation applies. The lives selected to govern the time of vesting must not be so numerous or so situated that evidence of their deaths is likely to be unreasonably difficult to obtain. It is intended by the enactment of this section to make effective in this State the American common-law rule against perpetuities." CAL. Crv. CoDE $\$ 715.2$.

"See generally Leach, Perpetuities in Perspective: Ending the Rule's Reign of Terror, 65 HARv. L. REv. 721 (1952); Leach, Perpetuities: New Absurdity, Judicial and Statutory Correctives, 73 HARv. L. REv. 1318 (1960); Lynn, A Practical Guide to the Rule Against Perpetuities, 1964 Duke L.J. 207.

The most flagrant examples of transactions voided because of a mere possibility of not vesting within twenty-one years are what one authority has called the "administrative contingencies" type, the "fertile octogenarian" type, and the "unborn widow" type. Leach, Perpetuities in a Nutshell, 51 HARv. L. REv. 638, 642-46 (1938).

${ }^{3}$ Several states have modified the common law Rule Against Perpetuities by passing statutes abrogating the orthodox interpretation of the Rule. See, e.g., ILL. REv. STAT. ch. 30, $\S 153 a$ (1951) (vesting not postponed merely because the limitation is to take effect upon the probate of a will); IDAHO CODE ANN. \$ 55-111 (1957) (rebuts common law presumption of the ability to have children at any age). Other states have changed the Rule by "wait and see" and "cy pres" statutes. See, e.g., MAss. GEN. LAws ch. 184A, $\$$ 1, 2 (1954); PA. STAT. ANN. tit. 20, 301.4 (b) (1947). See generally Lynn, supra note 2 .

386 P.2d 817, 35 Cal. Rptr. 241 (1963).

-The lease agreement provided that the lessor was to begin construction "upon approval of completed plans and specifications" and was to "continue expeditiously" subject to such delays as strikes and shortages of materials. The building was to be finished within ninety days after the issuance of the building permit. 386 P.2d at 820,35 Cal. Rptr. at 244.
} 
installation of a sprinkling system, and on appeal the lessee raised the issue of the Rule Against Perpetuities. ${ }^{\circ}$ The appellate court declared the lease invalid on the ground that the lessee's interest would not necessarily vest within the Rule's period, because the building might be incomplete after twenty-one years. ${ }^{7}$ The supreme court, however, reversed on the basis of its finding that under contract law the building would have to be finished "within a reasonable time" which under the circumstances was less than twenty-one years. ${ }^{8}$

The Rule Against Perpetuities originated in a non-commercial atmosphere as a means of avoiding family conveyances which tended to tie up property for long periods of time.9 While there can be little doubt of the past and present validity of the Rule's purposes, ${ }^{10}$ there is ample support for the view that the Rule should not apply to modern commercial transactions. ${ }^{11}$ The Restatement of Property reflects this policy in sustaining options to purchase or to obtain new leases during the lease term, despite the fact that the lessee may exercise the option beyond the Rule's period. ${ }^{12}$ This practice is commercially reasonable since options in favor of lessees make the leases

The question of the Rule Against Perpetuities arose out of the oral arguments before the District Court of Appeal. Neither the lessor nor the lessee had raised the issue prior to this time. 386 P.2d at 822 n.9, 35 Cal. Rptr. at 246 n.9.

7 Wong v. DiGrazia, 29 Cal. Rptr. 86 (Dist. Ct. App. 1963).

${ }^{8}$ The court felt that a failure to approve the plans, inability to procure the building permit, or a strike would not alter the lessor's obligation to finish the building within a reasonable time, which was less than twenty-one years. See note 5 supra.

o See generally 5 Powell, Real Property Iף 759-62 (1962); 4 Restatement, ProperTy, PT. I, Introductory Note at 2123.33 (1944); 3 SIMEs \& SMITH, FuturE INTERESTS $\$ \S 1211-21$ (1956).

10 "First, the Rule Against Perpetuities strikes a fair balance between the desires of members of the present generation, and similar desires of succeeding gencrations, to do what they wish with the property which they enjoy.

"But, in my opinion, a second and even more important reason for the Rule is this: it is socially desirable that the wealth of the world be controlled by its living members and not by the dead." Simes, The Policy Against Perpetuities, 103 U. PA. L. REv. 707, 723 (1955).

1x See Leach, Perpetuities in a Nutshell, 51 Harv. L. REv. 638, 660 (1938); Leach, Perpetuities in Perspective: Ending the Rule's Reign of Terror, 65 Harv, L. REv. 721,737 (1952); Leach, Perpetuities: New Absurdity, Judicial and Statutory Correctives, 73 HARV. L. REv. 1318, 1321-22 (1960); Lynn, supra note 2, at 212.

${ }^{2}$ Restatement, Property \& 395 (1944); Dozier v. Troy Drive-In-Theatres, Inc., 265 Ala. 93, 89 So. 2d 537 (1956) (option to purchase during ninety-nine year lease allowed); Roemer v. Sinclair Ref. Co., 380 P.2d 56 (Colo. 1963) (no violation of the Rule in a purchase option for a lease which continued for twenty-nine years); Smith $v$. Aggregate Supply Co., 214 Ga. 20, 102 S.E.2d 539 (1958) (valid to have a perpetual lease or a perpetual right to renew a lease). Contra, Epstein v. Zahloute, 99 Cal. App. 2d 738, 222 P.2d 318 (Dist. Ct. App. 1950) (perpetual right to renew lease not allowed); First Huntington Bank v. Gideon-Broh Realty Co., 139 W. Va. 130, 79 S.E.2d 675 (1953) (lessee's option to purchase at the end of a twenty-eight year lease held void). 
more desirable and thus more alienable.13 On the other hand, since options in gross ${ }^{14}$ may tie up the property indefinitely and make it impractical for the owner to improve his property, such options are not valid if exercisable beyond the time limit of the Rule. ${ }^{15}$ The fact that in many commercial cases property is not in reality tied up has fostered the view that courts should not impose any requirement of vesting or failing within twenty-one years in this areà. ${ }^{16}$ To effectuate such a change in the Rule, advocates of this point of view propose statutory revisions which would largely confine the Rule's strictures to non-commercial areas where business realities do not demand unrestricted property interests. ${ }^{17}$

Because of a dearth of cases concerning "on completion" leases, the Wong court had little authority on which to rest its decision. The single California case on point, Haggerty $v$. City of Oakland, ${ }^{18}$ involved a ten-year lease to commence upon completion of construction; the lease was held unenforceable since there was a "bare possibility" that it would not vest within twenty-one years. The court expressly rejected the contention that the building would have to be completed within a reasonable period and held that the Rule should be strictly applied in a uniform manner. On the other hand, in a similar case in another jurisdiction involving an agree-

${ }^{13} 3$ SiMES \& SMrTh, FutURE INTERESTS $\$ \S 1243$, 1244 (1956). Allowing options to purchase also encourages improvements on the part of the lessee since he is assured that he may elect not to give up the property at the end of the term.

14 Options in gross are those not appurtenant to a lease or other interest in the property.

15 Restatement, Property $\$ 394$ (1944). See Rocky Mountain Fuel Co. v. Heflin, 148 Colo. 415, 366 P.2d 577 (1961). But see Mattern v. Herzog, 367 S.W.2d 312 (Tex. 1963), in which an option in gross to purchase was upheld on the ground that it was to be exercised within a reasonable time. The court states, "When the wording of the option does not compel a construction that the parties intended that the time element should be unlimited, the court will not construe an option contract or a will provision granting an option to run for an indefinite time and thus destroy the validity of the option provision. It has been stated that the courts will go so far as to imply a reasonable time when no time limit is expressly stated." Id. at 319. For note approving the case see 39 NOTRE DAME LAw. 211 (1964).

${ }^{16}$ See note II supra.

${ }_{17}$ Leach, Perpetuities in Perspective: Ending the Rules Reign of Terror, 65 HARv. L. REv. 721, 747 (1952), calls for "legislation which will retain the virtues of the Rule Against Perpetuities while eliminating its tendency to destroy interests which offer no threat to the public interest." See Leach, Perpetuities: New Absurdity, Judicial and Statutory Correctives, 73 HARv. L. REv. 1318, 1324 (1960); Lynn, supra note 2, at 209.

18 151 Cal. App. 2d 407, 326 P.2d 957 (Dist. Ct. App. 1958). For discussions favorable to this case, see Jones, The Rule Against Perpetuities as It Affects California Oil and Gas Interests, 7 U.C.L.A.L. REv. 261, 278 (1960); 39 N.C.L. Rev. 93 (1960); 35 N.D.L. REv. 170 (1959). For views opposed to it, see Leach, Perpetuities: New Absurdity, Judicial and Statutory Correctives, supro note 17; 10 Hastings L.J. 439 (1959). 
ment to enter into a lease within twenty days after the lessor had acquired the property and obtained zoning for commercial purposes, the contract was upheld. ${ }^{19}$ There the lessee's interest was said to vest when the agreement to lease was executed rather than when the lease commenced. The court also stated that the reasonable time doctrine would require vesting within twenty-one years but rested its decision on the former ground.

With this background, the court in Wong came to a conclusion which necessitated an explicit overruling of the Haggerty decision handed down five years earlier. The Wong court based its opinion on an underlying decision not to apply the Rule rigidly in commercial areas in general and not to apply it to "on completion" leases in particular. Implicit in this reasoning was a rejection of what the court considered to be two improper assumptions: first, that courts are not to use principles of reasonable construction in cases involving the Rule; second, that an otherwise valid agreement is voided if there is a possibility that it will be broken and remain unremedied for over twenty-one years. ${ }^{20}$ As to the first assumption, the court recognized that most commercial leases are intended to vest within short periods of time and that only under the most unforeseeable circumstances will the preliminary transactions not have been concluded within the Rule's period. With this in mind, the court apparently felt that the usual rules of construction, especially the reasonable time requirement, would furnish the courts sufficient means to uphold harmless agreements while at the same time leaving them free to curb transactions which do in fact tie up property. ${ }^{21}$ Secondly, the court rejected the argnment that the agreement was void because the lessor might not finish the building and the lessee might choose not to enforce the contract within twenty-one years. The court pointed out that the argument would apply equally well to a contract which provided that it was to be completed within twenty-one years, and yet there is no doubt that such a contract would be valid under the Rule.

\footnotetext{
${ }^{19}$ Isen v. Giant Food, Inc., 295 F.2d 136 (D.C. Gir. 1961), 37 Notre Dame Law. 561 (1962), 19 WASH. \& LEE L. REv. 91 (1962). Cf., Francis v. Superior Oil Co., 102 F.2d 732 (10th Cir. 1939) (oil and gas lease for five years from date on which lessce could legally enter and drill held valid, since lessee got a present interest, sometimcs called a profit à prendre); Southern Airways Co. v. DeKalb County, 216 Ga. 358, 116 S.E.2d 602 (1960) (fifteen year lease to begin when airport completed allowed on the ground that since the lessee was to get no interest in the land, the relationship was that of landlord and tenant, and the Rule was inapplicable).

20386 P.2d at 824, 35 Cal. Rptr. at 248.

2I See 3 Simes \& SMITH, FutURE INTEREsts § 1228 (1956).
} 
On the other hand, a strong dissent in Wong questions the majority's conclusion that the Rule's application should depend only upon a reasonable probability that the lease would vest within twenty-one years and the court's assumption that the Rule is an anachronism in modern commercial practice. ${ }^{22}$ The dissent points out that historically the common law Rule would void a transfer on a bare possibility of a failure to vest within the period, and that California's constitution and statute together expressly adopt the common law Rule with no modification. ${ }^{23}$ Furthermore, the California legislature had before it the Haggerty decision striking down "on completion" leases and yet had taken no steps toward amending the statute. The dissent accepted this as a legislative mandate to continue the application of the Rule in its strict common law form. ${ }^{24}$

The Wong case is an important step in the relaxation of the requirements of the Rule Against Perpetuities. Modern commercial realities demand unfettered property transactions. The court seems to be correct in its assumption that these same realities will of themselves keep property moving freely in commerce while the principles of construction provide a means of enforcement of the policy behind the Rule. Certainly there are no compelling arguments for striking down "on completion" leases other than those seeking certainty in a mechanistic application of the Rule. However, the court is arguably usurping a legislative function if it is reading a commercial exception into the Rule rather than merely applying already existing rules of construction in concluding that the agreement was valid under the Rule. Despite this possible criticism, the Wong decision is supportable from a policy standpoint and reflects legislative intent recently manifested in a California statute requiring a more liberal interpretation of the Rule Against Perpetuities. ${ }^{25}$

22386 P.2d at 830-31, 35 Cal. Rptr. at 254-55. The dissenting justice was the author of the majority opinion in the Haggerty case. See note 18 supra and accompanying text.

23 "No perpetuities shall be allowed except for eleemonsynary purposes." CAL. Const. art. $20, \S 9$ (1879). For the statutory provision, see note 1 supra.

${ }^{26} \mathrm{But}$ see note 25 infra.

${ }_{20}$ "No interest in real or personal property is either void or voidable as in violation of Section 715.2 of this code if and to the extent that it can be reformed or construed within the limits of that section to give effect to the general intent of the creator of the interest whenever that general intent can be ascertained. This section shall be liberally construed and applied to validate such interest to the fullest extent consistent with such ascertained intent." CaL. Crv. CoDE $\$ 715.5$ (1963).

"No interest in real or personal property which must vest, if at all, not later than 60 years after the creation of the interest violates Section 715.2 of this code." CAL. Crv. CoDE $\S 715.6$ (1963). 